El Ammar, C., El Hajj, W., Kataya, A.

BEIRUT EXPLOSION AND CEDRE IMPLEMENTATION: THE LAST OPPORTUNITY FOR EFFECTIVE CORPORATE

AND PUBLIC GOVERNANCE

\title{
BEIRUT EXPLOSION AND CEDRE IMPLEMENTATION: THE LAST OPPORTUNITY FOR EFFECTIVE CORPORATE AND PUBLIC GOVERNANCE
}

\author{
Charbel EL AMMAR \\ Ph.D. Candidate, Bucharest University of Economic Studies, Romania \\ charbel.alammar@gmail.com \\ Wissam EL HAJJ \\ Ph.D. Candidate, Bucharest University of Economic Studies, Romania \\ whaij@damana.com
}

\author{
Abdo KATAYA \\ Ph.D. Candidate, Bucharest University of Economic Studies, Bucharest, Romania, \\ boudyatayaa@hotmail.com
}

\begin{abstract}
In any nation across the world, effective governance involves improving the lives of all, providing value for new generations, consistent allocation of duties and functions, accountable decisions, providing quality of information, transparency and responsibility, good performance, a strong legal system, and above all developing sustainability on all levels. Governance is rooted and established based on the collaboration and coordination among nation's governments, organizations, and people. The sluggishness in setting such governance goals as well as the incapability of many governments, like the Lebanese one, to develop and execute adequate legislative and institutional initiatives coupled with the absence of corporate governance knowledge, given that organizations remain connected to their elderly conventional method to manage their businesses that are based on nepotism, corruption legislation, and sectarian distribution, represent a crucial challenge for any reform and good governance endeavor. This paper aims to approach the need for Lebanon to reconsider new governance strategy and organizational and institutional reforms, especially, in conjunction with the severe economic crisis facing the country, the explosion of the port of Beirut on August 4, 2020, and the awaiting implementation of CEDRE project. The analysis revealed that moving to a new perspective in a complicated social and political environment, like Lebanon, involves multiple aspects. As a result, an in-depth implementation of a New Lebanese Public Governance in Lebanon along with political stabilization must lead to a progressive structural administrative reform and change which will also contribute to boosting confidence with the international community and speed up the international financial donation and support that will help Lebanon to heal its wounds and rise again. The defiance is to figure out if this could be another lost opportunity.
\end{abstract}

Keywords: Corporate Governance, Capital Investment Plan, New Public Governance, Public Administration, Strategic Reform. 


\section{INTRODUCTION}

August 4, 2020, is a date that Lebanese people won't forget due to the explosion of Beirut's port that hit and destroyed the artery and the main and essential nerve of the Lebanese economy. This situation occurred due to a series of factors such as: the absence of responsibility, bad performance, political conflicts, the inefficient legal system, lack of accountability and transparency, the lack of legislation of corruption, and inconsistency in the allocation of duties and functions. Also, it is an example of what poor governance can cause. There is no good and effective governance if it is not rooted and established based on communication and collaboration between all member states, government, organizations, and people (Johnston, 2012). Corporate governance is the structure of laws, relations, functions and procedures within and by which corporate control is exercised and regulated. It involves the processes by which businesses and those in charge are kept to accountability. Corporate governance affects how business goals are realistic and accomplished, how uncertainty is managed and evaluated, and how success is measured (Council, 2007). Efficient corporate governance frameworks enable businesses to build value through entrepreneurial spirit, creativity, growth, transparency, and by developing control mechanisms customized to the associated risks. In any corporate governance framework, it is important to determine the management and executives' tasks, with a combination of expertise, qualifications and accountability in the board in conformity to the nature and scope of the organization's activities. For those who can affect the strategy and financial results of a business along with sustainable and ethical judgment, there is a fundamental necessity for credibility. To increase transparency and resources, meeting the knowledge needs of a modern investment community is also crucial. Communicating the financial and non-financial company's performance calls for implementing procedures that maintain the credibility of company reports, and provide an accurate and balanced image of all relevant matters. The rights of all stakeholders need to be addressed, managed, and safeguarded. Each strategic decision has a level of doubt and raises a threat that can be controlled by careful monitoring and an effective internal control system. Incentives are also crucial to motivate the qualified staff to deliver the value that owners need. Public governance handles the interests of a state at all stages by involving people in decision-making process affecting their interests and existence. Thus, all crucial players, as business corporations, financial institutions, non-governmental organizations, and public institutions must undertake different responsibilities as a part of their significant contributions is to improve overall governance at all state levels. The law's implementation and the constitutional procedures and sanctions toward those who don't abide by such guidelines are to be adopted and imposed by representatives of the regulatory bodies of governmental organizations that have to exert significant control and authority. However, this is challenging in a nation which has experienced several struggles and 
disputes over the previous years, and where, based on studies, the level of corruption acts in these particular institutions have attained significant rates. The interconnection between corporate and economic governance is a must (Dixit, 2009). It enables a greater perception and knowledge of the particularities of the principle of governance in Lebanon. According to Dixit (2009), economic governance affects corporate governance. In Lebanon, poor structured governance is expected because the government lacks the ability to deliver governance while private organizations are left to operate and meet the necessary requirements and implement their standards. Thus, corporate governance should be viewed in the sense of the broader structure and economic system through which it is being analysed. Corporate governance is a key factor in the improvement of micro economic performance that influence the operation and growth of financial sector and has a significant impact on the distribution of resources (Maher \& Andersson, 1999). Considering corporate governance and its consequences would deliver strategic support that could assist in forming a framework for recognizing its complexities. Thus, the study does not describe corporate governance as a mechanism through which organizations are guided and regulated (Cadbury, 2000); or even as the framework of duties and obligations between the groups who are tied up in the organization (Aoki, 2001). The study addresses a conceptual framework based on corporate and New Public governance in public service organizations. In addition, the research conducts a framework which summarizes the Lebanese government practices from Paris I passing through Paris II and III till CEDRE. The framework formulated in this paper serves as a guide for the Lebanese government to benefit from the last opportunity to implement corporate governance principles and apply effective new public governance.

\section{CONCEPTUAL FRAMEWORK}

\subsection{Corporate Governance in Public Service Organizations}

Effective corporate governance has turned out to be a measure of success for analysing a state's future growth and development. Without effective corporate governance, the entire state cannot reach sustainable development. Effective governance in public service organizations performs a significant function in the community, promote efficiency and transparency in allocating and managing resources, enhance administration and the way of delivering services, and leads to the enhancement of citizen's life quality (International Federation of Accountants (IFAC), 2001). Thus, improving corporate governance in public service organizations throughout the globe should be a matter to be treated with careful attention. Effective corporate governance requires a strong structure of public administration (Hontz, Shkolnikov, \& Abell, 2009). In public service organizations, governance includes the process through which targets are set and 
achieved, requires initiatives that maintain government legitimacy, provide services equally, minimize the threat of bribery and corruption, and maintain public representative's suitable and proper conduct (IIA, 2006). Regardless of the reality that the generality of descriptions provided to corporate governance is linked to private industry context, some researches declared that corporate governance is the commitment tasks of the executive committee of any specific corporation (Hardman, 1996). Furthermore, corporate governance is described as a platform by which firms and organizations are adequately managed, planned, and guided (Cadbury Committee, 1992). Through such interpretations, researchers contend that the corporate governance standards are generally identical in private industryas well as in public service organizations (Barret, 1997).

Corporate governance in public service organizations is fundamentally related to making choices and taking decisions that lead to boost the quality of performance and enhance the effectiveness of accountability and transparency (Barret, Corporate Governance, 1998). Researchers stated that corporate governance agrees with ways and directions through which organizations are directed and controlled (Plessis, Hargovan, \& Bagaric, 2011). Whereas, other researchers considered that corporate governance represents processes by which institutions and entities maintain openness or transparency, accountability, and integrity (Horwood, 2001). Strong corporate governance structures are intended to play a wide role in promoting effective governance (Ryan \& Ng., 2000). In addition, a strong corporate governance structure develops a scope that release managers from their commitments (Roundtable, 2002). The establishment of a good corporate governance structure is recognized as an important method that could limit any unintended effects (Ryan \& Ng., 2000). Based on that, the focus should be considered significant in supporting the appearance and implementation of an efficient corporate governance structure (Hepworth, 1994). Indeed, a detailed framework of governance in public service organizations must be well defined and established (New South Wales Audit Office, 1997). In the United Kingdom, corporate governance policy in public service organizations is more inherent and implicit than explicit and clear (Horwood, 2001). Even so, several countries in Asia and West and East Europe have shown interest in the reform of the corporate governance structure (Porta et al., 2000). Under different contexts, the governance structure tends to evolve as a response to changes in historical and geographical settings, government administration, rules and regulations, and political exemption (Kersbergen \& Waarden, 2004). Many US companies are well supported and represented by senior executives (Roundtable, 2002). In other words, senior executives have the duty of maintaining good corporate governance inside these firms. Thus, in public service organizations, corporate governance must be considered as a priority. Good corporate governance in public service organizations is crucial for enhancing public trust in public and governmental organizations (International Federation of Accountants (IFAC), 2001). Similarly, it will avoid corruption and bribery, the waste of 
resources and the inadequacy of public service delivery (Hontz, Shkolnikov, \& Abell, 2009). The Public Life Standards Committee (PLSC) have shown interest in the appropriate development of a well-established corporate governance structure in the context of public service organizations (Nolan, 1995). Sound corporate governance framework within any organization represents a functioning process through which objectives are set, accurate decisions are taken, and adequately regulate compliance and efficiency (Roundtable, 2002). Managing risk is considered an integral aspect of corporate governance in public service organizations. For instance, Horwood (2001) stated that attaining good corporate governance in public service organizations is not possible without recognizing the influence of risk management effectively. Managing risk provides several advantages to corporate governance including organizational and fiscal management, proper method for continuous change and reform strategy, optimizing prospects and reducing waste outcomes. Similarly, IFAC (2001) suggested that managing risk in effective manners in all public service organizations would lead to a sound corporate governance structure. Good corporate governance includes a comprehensive knowledge and awareness of the managerial functions and their relationships within the organizational context (Roundtable, 2002). Organizations' managers must guarantee and maintain risk management, develop strategic plans, and implement reporting methods, effectively and efficiently. Governance is quite necessary since it is an integral way of enhancing a state's economic development, evaluating the quality of governmental rules and legislation, acting as an approach of deciding whether public organizations are following the government's agenda, and meeting public demands and desires through an appropriate code of behaviour (ICANZ, 2003). Effective corporate governance impacts, a nation's growth significantly (Hontz, Shkolnikov, \& Abell, 2009). The International Federation of Accountants (2001) offered certain suggestions that could enhance corporate governance in public service organizations, including the following:

- The principles of conduct consisting of leadership, rules of behaviour and rationality, ethics and integrity.

- The organization's systems and procedures including legal responsibility, public funds transparency, stakeholder engagement, and functions and duties.

- The control process including managing risk, internal auditing, efficient performance and budgetary control process, management of fiscal resources, and employee's development.

- The external reporting including; annual reporting, implementation of useful accounting principles, performance evaluation measures, and external auditing.

\subsection{Basics of Corporate Governance in Public Service Organizations}


While there is no particular method that applies to all companies (Roundtable, 2010), most public service organizations operate based on multiple methods included in their organizational procedures (Roundtable, 2002). However, governance standards are highly relevant to public service institutions that adopt the strategies, systems, and procedures used to supervise and manage their various operations and goal accomplishment (IIA, 2006). The corporate governance basics applied in private industry are roughly equivalent to the public ones (Horwood, 2001). Despite that, it is difficult to provide a common governance structure and guidelines that will be suitable for all public service organizations. Yet, identical rules could be applied, if these governing entities are elected or chosen (International Federation of Accountants (IFAC), 2001). The Institute of Chartered Accountants of New Zealand (2003) contended that what could be learned from effective corporate governance in the private sector is completely missing in the context of the public industry. However, based on certain concepts, many developed states are producing and creating efforts to raise the performance of the corporate governance structure in their public service organizations. For example, in the United Kingdom, the Cadbury report put the basis for the development of the first framework of corporate governance in public service organizations through the Chartered Institute of Public Finance and Accountancy (CIPFA, 1995), that subsequently adjusted the report to be in accordance with the conditions of the public service organizations, which are based on openness, accountability, and integrity (Ryan \& Ng., 2000). Such values are highly important and essential for all organizations in public service, because they belong to the private industry structure (International Federation of Accountants (IFAC), 2001). This implies that people's integrity, accountability and openness in public service organizations represent the cornerstone that leads to a successful corporate governance framework. Therefore, the Chartered Institute of Public Finance and Accountancy urges the adoption of transparency, accountability, integrity in governing and managing government financial resources, administration of operations, and performance quality throughout every corporate governance system (Ryan \& Ng., 2000). Likewise, the importance of corporate governance is based on its specific characteristics that involves justice, transparency, responsibility, accountability, and equality (Hontz, Shkolnikov, \& Abell, 2009). The Institute of Internal Auditors (2006) stressed that the standards and basics of corporate governance relevant to public service organizations are specific to these organizations and involve the following: the concepts of openness, transparency, integrity, and accountability. Consequently, public service institutions are expected to adhere to these principles in order to enhance the quality of their organizational context. Nolan (1995) presented seven standards to be implemented in the corporate governance system of public service organizations including; transparency, leadership, selflessness, rationality, fairness, accountability and truthfulness. Furthermore, Horwood (2001) clarified many of the basic corporate governance practices that are applied in public service institutions 
including society's attention, service provision commitments, risk management functions and procedures, internal monitor, and behavioural norms.

\subsection{New Public Governance}

There are three main types of governance in literary texts. First, corporate governance associated with the inner structures and procedures that extend guidance and transparency to every institution; second, effective governance associated with the spread of conceptual patterns of governance, socially, politically, and administrative governance through transnational organizations and institutions; third, New Public Governance that described the challenges of public strategy adoption and provision of services within the hierarchical and pluralistic structures of the country (Osborne, 2010). Actually, New Public Governance is deeply ingrained in organizational and system philosophy (Nohria \& Eccles, 1992). New public governance postulates a collective system, whereby large collaborative players participate in public service provision, and a pluralism system, whereby various mechanisms guide the structure of policy decisions. It is associated with the organizational and outer environmental influences that allow and restrict the development of government policy and the provision of public services and benefits within such a collective and pluralism structure; thus, making it the useful and appropriate resolution to the existing situational issue in Lebanon. New public governance is the cross-institutional communication between the public and private sectors, and also NGOs with the objective of linking all available governance opportunities and assets to fix and resolve the communities' issues (Patapas, 2014). It focuses on governing procedures, emphasizing service quality, and results that depend on governmental engagement with its setting. Therefore, new public governance represents a tool and an answer to the growing complexity, collective, and decentralized structure of public policy adoption and provision of public service (Osborne, 2010). The basics of new public governance are described in seven different topics. First of all, the basic topic which is related to the key component of evaluation in investigating and exploring the adoption of public strategy and provision of public services, in addition to the impacts of principles and operation; second, the structural and design that is related to organization structure and design that perfectly adapted for providing public services in the whole country; third, sustainable development topic that is related to the sustainability of public service structures and the implications and results related to sustainable development; fourth, the values that are related to the quality and value that boost and support the adoption of government and public policy and strategy and the provision of services to the public; fifth, the required competence that is related to the main competencies and knowledge needed for a quality performance; sixth, accountability that is related the characteristics of accountability in collective and decentralized structure, and finally; the assessment that is related to the 
El Ammar, C., El Hajj, W., Kataya, A.

BEIRUT EXPLOSION AND CEDRE IMPLEMENTATION: THE LAST OPPORTUNITY FOR EFFECTIVE CORPORATE AND PUBLIC GOVERNANCE

evaluation and measurement of sustainable development, efficiency, and accountability throughout an open framework of delivering public services. Such topics must be illustrated clearly and properly if a government and public service organizations decide to implement new public governance.

Indeed, effective planning of public strategy is a significant measure of new public governance taking into account the aspects of global development to manage inner nation variables and external environmental components and matters, to ensure foreign support and help by combining and implementing finest and greatest public governance procedures (Patapas, 2014). Such a fundamental shift was a critique of the conventional model of public administration that stressed impersonation, institutionalization and strict definition of reasoning. The conventional public administration concept was a political invention of an industrialized era of huge production and significantly enhanced the quality of operation and function work at that moment.

New public management was conceptually established on conventional management of business and economy. It was distinct from the bureaucratic structure, promoting and stressing the bilateral role and function of the market and public administration. Yet, in allocating public resources and fixing the public issue such a paired role and function concentrated excessively on market influence, but it neglected the impact of other institutions in government administration. New public governance stressed pluralism as a modern model of study in public administration research, added huge relevance to the relations among institutions internally and externally, and concentrating on institutional governance. Table 1 offers a brief description of the conceptual transformations described.

Table 1. Relation between Conventional public administration, New Public Management, and New Public GOVERNANCE

\begin{tabular}{|l|l|lr|l|}
\hline & $\begin{array}{l}\text { Conventional Public } \\
\text { Management \& Public } \\
\text { Administration }\end{array}$ & $\begin{array}{l}\text { New } \\
\text { Management }\end{array}$ & New Public Governance \\
\hline $\begin{array}{l}\text { Quality } \\
\text { Guidance }\end{array}$ & System and Process & $\begin{array}{l}\text { Effectiveness and } \\
\text { efficiency }\end{array}$ & $\begin{array}{l}\text { Efficiency, effectiveness, } \\
\text { and democracy }\end{array}$ \\
\hline $\begin{array}{l}\text { Conceptual } \\
\text { Standard }\end{array}$ & $\begin{array}{l}\text { Bureaucracy, } \\
\text { administrative, and } \\
\text { political dilemma }\end{array}$ and & $\begin{array}{l}\text { The concept of } \\
\text { economy, the ideology } \\
\text { of private sector } \\
\text { operations }\end{array}$ & $\begin{array}{l}\text { Contractual-ism, the } \\
\text { philosophy of integrity, } \\
\text { socialism }\end{array}$ \\
\hline $\begin{array}{l}\text { Code } \\
\text { conduct }\end{array}$ & $\begin{array}{l}\text { Isolating strategy and } \\
\text { implementation, } \\
\text { centralization in public } \\
\text { administration }\end{array}$ & $\begin{array}{l}\text { Privatization and } \\
\text { promotion of public } \\
\text { services }\end{array}$ & $\begin{array}{l}\text { People } \\
\text { democratic discourse, } \\
\text { and pluralist governance }\end{array}$ \\
\hline $\begin{array}{l}\text { Community } \\
\text { function }\end{array}$ & $\begin{array}{l}\text { Leader } \\
\text { Client }\end{array}$ & $\begin{array}{l}\text { Engagement in the } \\
\text { decision-making process }\end{array}$ \\
\hline
\end{tabular}




\section{El Ammar, C., El Hajj, W., Kataya, A. \\ BEIRUT EXPLOSION AND CEDRE IMPLEMENTATION: THE LAST OPPORTUNITY FOR EFFECTIVE CORPORATE \\ AND PUBLIC GOVERNANCE}

Source: Xu et al., 2015.

The provision of public and government services has changed over the recent four decades from a public administrative concept, passing by New Public Management, toward an appropriate and suited public administration concept in the modern era which is the New Public Governance (Lindsay et al., 2014). New Public Governance is a fundamental shift in the function and purpose of government and its interactions with public community (Pestoff et al., 2012). Actually, New Public Governance explores the facts of the adoption of public strategy and the provision of public and government services in the collective and pluralism dynamics of the nation (Osborne, 2010). New public governance stressed pluralism as the modern approach of public administration research, added special significance to the connections among public institutions internally and externally, and concentrated on institutional governance (Xu et al., 2015).

Eventually, the new public governance theory context or model features could be outlined in six components or attributes (Xu et al., 2015): first of all, new public governance illustrates the distribution of power and authority where all people in the community possess the right to engage in the management of public policy and in the resolution of public issues; second, new public governance emphasizes governmental cooperation by transforming the Governance from paternalistic to a community interest leader, creating discussion networks, incorporating public assets, achieve needs and desires from relevant concerns and fixing social issues and complexities; third, New public governance is a diverse system through incorporating social institutions and people in order to establish a comprehensive platform. Every major entity is limited by laws and regulations formally and informally, creating an interconnected structure of new public governance, community interactions, and engagement in a reasonably secure environment; fourth, new public governance structure is focused on the sharing of resources through which public goods and services could give an excess public resources to share including data, fund, and information and communication technology, in addition to the participation in managing public administration in order to meet multiple demands and desires from relevant concerns and people; fifth, new public governance depends on contractual confidence, reliability, and reputable representatives, meaning that it does not depend on constraints, limitations, precise and efficient regulations and processes, instead, on a sort unofficial confidence that renders new public governance structure further versatile, transferable, and modifiable; sixth, new public governance enhance the quality function of public administration and public service organizations by providing value and quality of the public services delivered by not making revenues and profits, instead, by fixing community issues through voluntary collaboration road. 


\section{CONTEXTUAL FRAMEWORK}

\subsection{Paris I toward Paris III: A Missing Chance to Reform}

On February 23, 2001, the date of Paris I conference, the Lebanese state confronted a challenging economic condition with a financial debt of about $25 \%$ of Gross Domestic Product, a debt to Gross Domestic Product rate of over $144 \%$, and interest premiums on government debt consuming and swallowing almost all of the governmental earnings. The main purpose of the Paris II meeting, held on 23 November 2002, was again to obtain global support and recognition for the Lebanese Reform agenda. Throughout this meeting, Lebanon obtained contributions amounting to US\$ 4.4 billion from a lot of nations and financial institutions such as, the International Monetary Fund, the World Bank, EU, and other international donor countries, organizations, and financial funds. Such responsibilities beside certain inner one from the financial industry, namely, the Lebanese banks, gave Lebanon an extraordinary chance for economic, social, political, and technological development that has not been noticed in history since the end of the Lebanese war.

Such developments include: reducing of the expansion of the governmental debt, substantially minimized governmental borrowing costs and the interest rate on lending in both Lebanese Pound and US dollardenominated debts, increasing foreign exchange earnings and profits of the Lebanese central bank, and improving trade balance in a significant and outstanding manner. Thus, the Paris II conference supported and assisted the Lebanese government to avoid an economic recession and fiscal disaster and paved the way toward economic recuperation, healing, and improvement.

Figure 1 illustrates the debt to Gross Domestic Product rate, between 2000 and 2007, during the period when the Paris III meeting was held. 


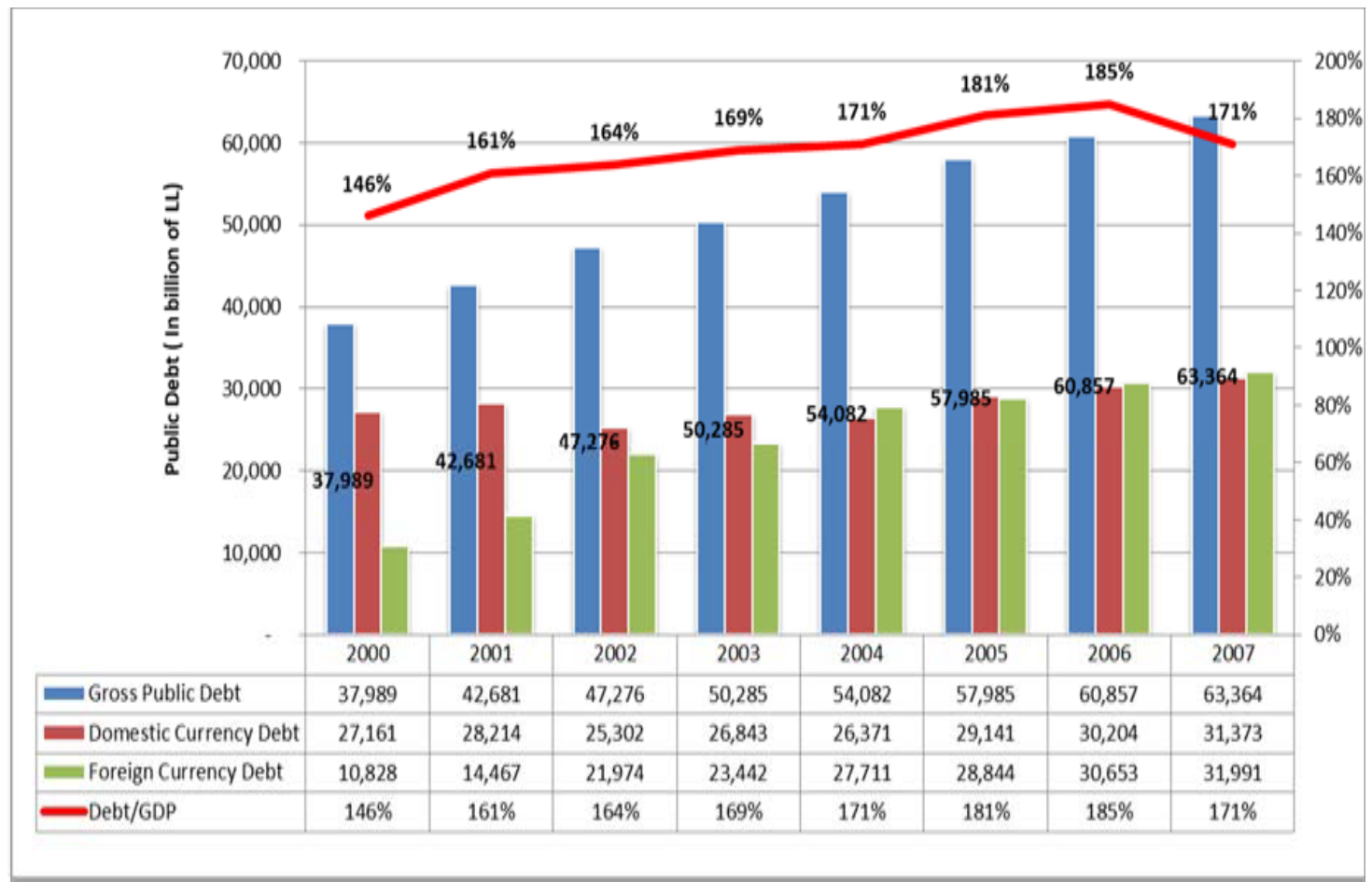

FIGURE 1. DEBT TO GROSS DOMESTIC PRODUCT RATE BETWEEN 2000 AND 2007

Source: Ministry of Finance - 2018

Following Paris II, on January 25, 2007, Paris III was born. The World Bank represented by the International Bank for Reconstruction and Development and the International Finance Corporation committed and promised about $930 \$$ million, from the $7.5 \$$ billion granted, in credit to help the Lebanese government in the context of Reform Implementation Development Policy Loan (RIDPL). That was the initial indicator which led to the lack of confidence of the international community in national government entities and officials opening the road for neo-institutionalism partnership with the Lebanese government.

Before approving the acceptance of the loan, Lebanon had presented to the World Bank executive committee, the reform agenda and the plan that would have been adopted. One of the main elements in the agenda was the reform plan for the energy and electricity sector and it included the following: the development of an internal ministry reform commission, grant agreements for consultancy company services for the Ministry of Energy and Water in order to support the reform process, assign electricity of Lebanon and HCP (Higher Council of Privatization) for the reform and re-organization of the electricity of Lebanon, and the appointment of internal or external auditors to investigate in electricity of Lebanon reports and accounts for the 2002-2006 period. From the overall $\$ 7.5$ billion promised at Paris III meeting, just $\$ 3.4$ billion, representing approximately $45 \%$ of the promised amount, has been approved. 
El Ammar, C., El Hajj, W., Kataya, A.

BEIRUT EXPLOSION AND CEDRE IMPLEMENTATION: THE LAST OPPORTUNITY FOR EFFECTIVE CORPORATE AND

PUBLIC GOVERNANCE

The goals and results of the three meetings are described in table 2 :

TABLE 2. GOALS AND RESULTS OF PARIS I, II, III FROM 2001 TO 2007

\begin{tabular}{|c|c|c|}
\hline Meeting & Goals & Results \\
\hline Paris I & $\begin{array}{l}\text { The goal was Lebanese economic growth. Lebanon put } \\
\text { forward its fiscal and economic agenda. Particularly, it } \\
\text { was agreed to appoint a more conference expanded to } \\
\text { include Lebanon's key economic collaborators and to } \\
\text { help the economy reconstruction plan of Lebanon. }\end{array}$ & $\begin{array}{l}\text { The conference brought up } \\
\text { approximately } 500 \text { million } \\
\text { Euros in international } \\
\text { assistance and help. }\end{array}$ \\
\hline Paris II & $\begin{array}{l}\text { The goal was to obtain international community } \\
\text { assistance to help Lebanese government minimize the } \\
\text { risk of government debt and change the financial, } \\
\text { social, and political inequalities of the economy in } \\
\text { Lebanon. The economic agenda proposed described a } \\
\text { plan which might result in a downward trend in the large } \\
\text { degree of governmental debt, a stabilization in the fiscal } \\
\text { position, and improved development opportunities } \\
\text { for being achieved. }\end{array}$ & $\begin{array}{l}\text { The Meeting results was } \$ 4.5 \\
\text { billion in US dollars: } \$ 3.4 \text { billion } \\
\text { for debt minimization and } \\
\text { control, and } \$ 1.5 \text { billion for } \\
\text { social development programs. }\end{array}$ \\
\hline Paris III & $\begin{array}{l}\text { The plurality of the funding was expected to assist } \\
\text { Lebanese reform endeavors in the form of awards, } \\
\text { representing } 25 \% \text {, and credits, representing } 75 \% \text {, either } \\
\text { for financial assistance or financial investments. }\end{array}$ & $\begin{array}{l}\text { The plurality of the funding was } \\
\text { expected to assist } \\
\text { Lebanese reform endeavors in } \\
\text { the form of awards, } \\
\text { representing } 25 \% \text {, and credits, } \\
\text { representing } 75 \% \text {, either for } \\
\text { financial assistance or financial } \\
\text { investments. }\end{array}$ \\
\hline
\end{tabular}

Source: Authors

\subsection{Capital Investment Plan (CIP) or CEDRE Project: A Road toward Reform}

On April 6, 2018, CEDRE, an international conference to support the Lebanon's development and reform was held in Paris with the participation of 48 countries, organizations and councils from the civil society and private sector. 
El Ammar, C., El Hajj, W., Kataya, A.

BEIRUT EXPLOSION AND CEDRE IMPLEMENTATION: THE LAST OPPORTUNITY FOR EFFECTIVE CORPORATE AND PUBLIC GOVERNANCE

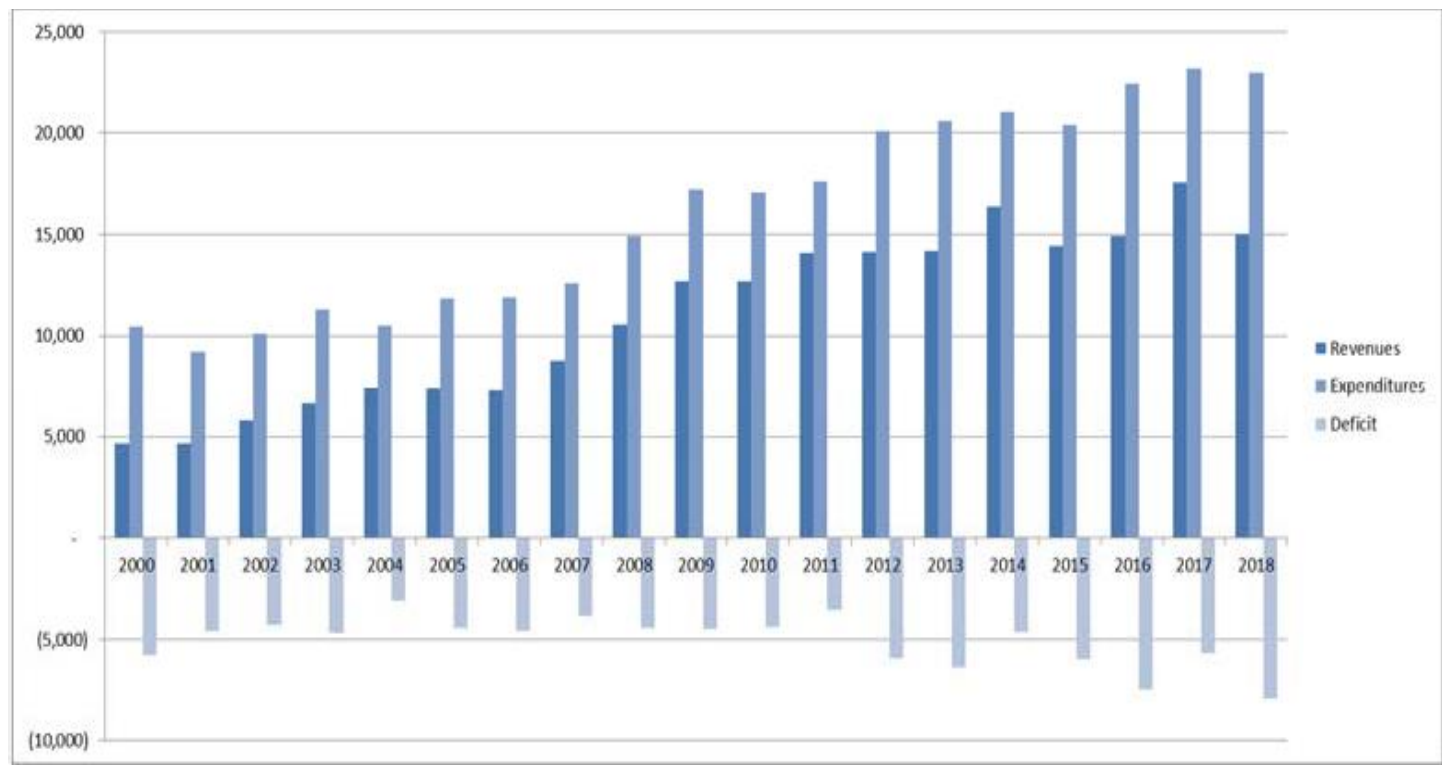

FIGURE 2. FINANCIAL PERFORMANCE BETWEEN 2000 AND 2018

Source: Ministry of Finance (2007)

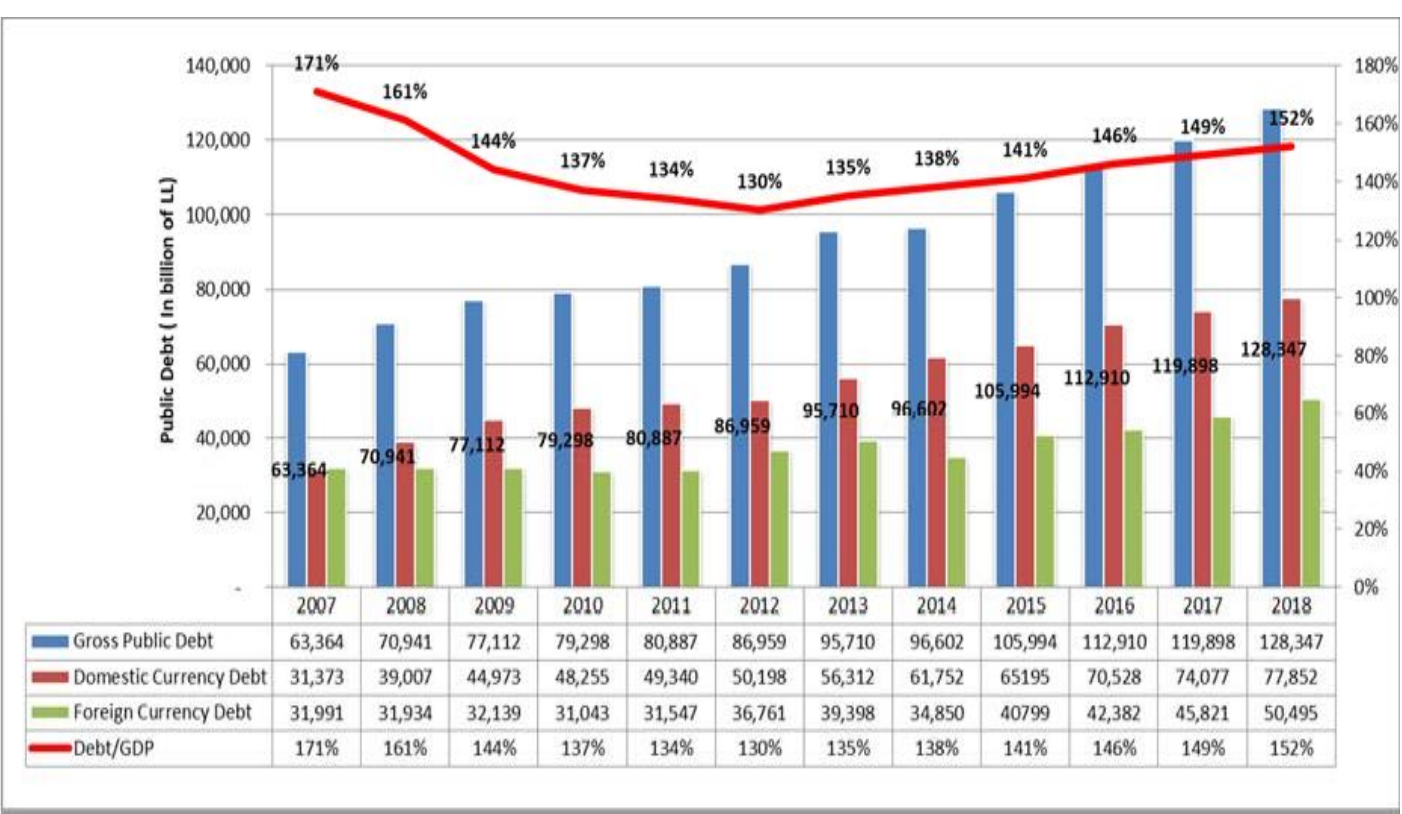

FIGURE 3. DEBT TO GROSS DOMESTIC PRODUCT RATE BETWEEN 2007 AND 2018

Source: Ministry of Finance (2008)

Given the current situation, Lebanon remained to face with deficiencies and growing challenges. The Syrian war consequences and the huge migration into Lebanon had a negative impact on the Lebanese economy, its social contributions, infrastructure, and led to a dramatic increase in the unemployment rate. 
El Ammar, C., El Hajj, W., Kataya, A.

BEIRUT EXPLOSION AND CEDRE IMPLEMENTATION: THE LAST OPPORTUNITY FOR EFFECTIVE CORPORATE AND PUBLIC GOVERNANCE

The Lebanese prime minister proposed the "Vision for Stability, Development and Jobs" to the Lebanese government, which all attendees accepted. This strategy is focused on four key elements: raising public and private investment levels, maintaining macroeconomic stability through fiscal consolidation, implementing critical sectoral reforms such as eliminating corruption, improving the public sector financial management, and adopting a plan to improve and diversify the economic development of Lebanon and achieve its trade opportunities.

The government introduced its comprehensive Capital Investment Program (CIP), which focused primarily on improving and rehabilitating the infrastructure. The first phase of the CIP will cost approximately US $\$ 10.8$ billion and will be implemented in six years.

TABLe 3. CEDRE Project: Financial Allocation Through SOURCe ANd Form

\begin{tabular}{|c|c|c|c|}
\hline & Loans & Grants & Total \\
\hline International Bank/Fund/Institution & & & 8.272 \\
\hline World Bank Group & 4.000 & & 4.000 \\
\hline European Bank for Reconstruction \& Development & 1.353 & & 1.353 \\
\hline European Investment Bank & 984 & & 984 \\
\hline Islamic Development Bank & 750 & & 750 \\
\hline Kuwait Fund for Arab Economic Development & 500 & & 500 \\
\hline Arab Fund for Economic and Social Development & 500 & & 500 \\
\hline European Union & 185 & & 185 \\
\hline National Government & & & 3.365 \\
\hline Saudi Arabia & 1.000 & & 1.000 \\
\hline France & 492 & 185 & 677 \\
\hline Qatar & 500 & & 500 \\
\hline Netherlands & 369 & & 369 \\
\hline Turkey & 200 & & 200 \\
\hline Kuwait & 180 & & 180 \\
\hline Italy & 148 & & 148 \\
\hline United States & & 115 & 115 \\
\hline UK & & 85 & 85 \\
\hline Germany & 74 & & 74 \\
\hline Japan & 10 & & 10 \\
\hline Finland & 7 & & 7 \\
\hline Total Funding Pledged & 11.252 & 385 & 11.637 \\
\hline
\end{tabular}

Source: Capital Investment Plan

Considering the context and commitment of the CIP and the World Bank Group's overall supportive analysis, attendees agreed to participate in the first stage of the plan while promoting the state's adoption of reforms and governmental strengthening, which are vital to the effective development of the project and the 
economic growth of Lebanon. Moreover, they stressed the need to prioritize the investments in water, energy and transport sectors which are vital for the quality of citizen's lives, as well as the need to adopt laws that govern the participation of the private sector in the execution of public projects.

The Lebanese government acknowledges the vital importance of introducing fundamental and macroeconomic initiatives to encourage new investments and introduce innovative and critical infrastructure. The government has pledged to reforms required to tackle systemic obstacles and vulnerabilities, and to support community investments in a viable manner. Concerning structural reforms, the Lebanese government stressed that adopting effective governance, enhancing transparency and accountability, including administering public finances, revamping purchasing laws, restructuring tariffs, and enhancing the performance of expenditures management are of prime significance. Furthermore, the Lebanese officials will strive to step up efforts to fight money laundering and to take action against this problem.

In order to make the Capital Investment Plan a success in the context of sectoral reform, three areas must be approached: with respect to energy, an aggressive tariff reform along with increased power generation; with regard to water management, the introduction of the Water Code is crucial; with regard to sewage treatment, a new policy is under way, focusing on decentralization. The participants considered that concessional financing and private investments in the infrastructure are the most important elements to decrease Lebanon's debt together with proper budgeting and program implementation. The participants committed in CEDRE to support the Lebanese government with $\$ 10.2$ billion as financial help and $\$ 0.86$ billion in grants, with the condition of applying the reforms mentioned in the CIP plan. The CIP seeks to modernize the country's economy by financing existing projects, launching new ones and introducing new initiatives to enhance trade, bring potential investors and create jobs and opportunities. The repeated pledges of change by the Lebanese government have lost their integrity and transparency: years of CEDRE discussions have already proved to the international community just how Lebanon is capable of reforming and fulfilling the contract terms. The political elite in Lebanon has never missed the chance to lose out on an opportunity to participate in meaningful economic change.

\subsection{The Effect of CEDRE Project on The New Lebanese Public Governance}

In reality, Lebanon's government continues to report systemic economic and fiscal vulnerabilities bearing a substantial load from the prominent adverse effect of regional political disruptions. These instabilities form major pressures particularly on the obsolete infrastructure which requires major investments in order to increase their support to the economy. Nevertheless, earlier unpleasant practices with the reform plans of the Lebanese State (Paris I, II and III) prompted CEDRE contributors to attach monetary payments with the 
El Ammar, C., El Hajj, W., Kataya, A.

BEIRUT EXPLOSION AND CEDRE IMPLEMENTATION: THE LAST OPPORTUNITY FOR EFFECTIVE CORPORATE AND PUBLIC GOVERNANCE

previous Capital Investment plan-based on structural and fiscal reforms, thereby raising accountability for all parties to ensure government adherence to the sound reforms. In order for the Lebanese government to be supported by the conditional CEDRE funds, the ultimate solution is to exercise New Lebanese Public management to apply the agreed reforms in different sectors. Table 4 represents the essential characteristics for the adoption of CEDRE project reform agenda as illustrated below:

TAble 4. The New Lebanese Public Governance Basis Characteristics for IMPLEMEnting the CEDRE REFORMS (CIP)

\begin{tabular}{|c|c|}
\hline Characteristic & xplanation \\
\hline $\begin{array}{l}\text { Highlighting the } \\
\text { Dissemination of } \\
\text { Control }\end{array}$ & $\begin{array}{l}\text { Creating a public private partnership to find solutions to the challenges } \\
\text { facing the public sector where everyone is involved in managing the public } \\
\text { affairs. The Lebanese officials must regulate the public decision-making } \\
\text { procedures in this relationship. }\end{array}$ \\
\hline $\begin{array}{l}\text { Enhancing } \\
\text { collaboration } \\
\text { government }\end{array}$ & $\begin{array}{l}\text { The Lebanese government role must be changed from that of } \\
\text { authoritarianism to a legislator and a collaborator of community interests } \\
\text { while forming full arguments and harmonizing public assets to assure the } \\
\text { satisfaction of the monitoring groups to find solutions to manage social and } \\
\text { economic hindrances. The Social and Economic Council established in } \\
2017 \text { is qualified to play this role. }\end{array}$ \\
\hline $\begin{array}{l}\text { Forming a complex } \\
\text { network }\end{array}$ & $\begin{array}{l}\text { A network including the public and private organizations, the civil } \\
\text { community, successful entrepreneurs, market analysts, must be formed to } \\
\text { employ their interdependent resources for the successful implementation } \\
\text { of new Lebanese public management. }\end{array}$ \\
\hline $\begin{array}{l}\text { Basing the Lebanese } \\
\text { governance network on } \\
\text { the resource exchange }\end{array}$ & $\begin{array}{l}\text { The New Lebanese Public Governance should implement a new system } \\
\text { of cooperation and sharing ideas in the management of public } \\
\text { administration to meet diverse requirements from areas of concern and } \\
\text { the people. }\end{array}$ \\
\hline $\begin{array}{l}\text { Basing on confidence } \\
\text { and stability contracts } \\
\text { and commitments for } \\
\text { the Lebanese } \\
\text { governance network }\end{array}$ & $\begin{array}{l}\text { Preserving equilibrium between the internal and external Monitor } \\
\text { Organizations should be focused on a revised trust-based special } \\
\text { contract; the New Lebanese Public Governance should assist the } \\
\text { Government of Lebanon in restoring its Institutional Integrity vis-à - vis the } \\
\text { International Community, which can contribute to greater independence. }\end{array}$ \\
\hline $\begin{array}{l}\text { Assessing the role of } \\
\text { social public } \\
\text { organizations }\end{array}$ & $\begin{array}{l}\text { The New Lebanese Public Governance should be public service focused } \\
\text { on the needs of the community. It is therefore necessary to reconsider the } \\
\text { potential value of public organizations reinterpreting the definition of public } \\
\text { corporations as social public organizations offering essential services not } \\
\text { only in order to make money, but also in order to solve problems in society } \\
\text { via voluntary cooperation. }\end{array}$ \\
\hline
\end{tabular}

Source: Authors 
El Ammar, C., El Hajj, W., Kataya, A.

BEIRUT EXPLOSION AND CEDRE IMPLEMENTATION: THE LAST OPPORTUNITY FOR EFFECTIVE CORPORATE

AND PUBLIC GOVERNANCE

No doubt that the implementation of CEDRE project will have a positive impact on the Lebanese economy for the next five years as estimated in the table below:

TABLE 5. THE IMPACT OF CEDRE PROJECT ON LEBANESE ECONOMY BETWEEN 2020 AND 2025

\begin{tabular}{|l|r|r|r|r|r|r|}
\hline Some Forecasted Economic Indicators & $\mathbf{2 0 2 0}$ & $\mathbf{2 0 2 1}$ & $\mathbf{2 0 2 2}$ & $\mathbf{2 0 2 3}$ & $\mathbf{2 0 2 4}$ & $\mathbf{2 0 2 5 f}$ \\
\hline Real GDP growth, at constant market prices (\%) & 1.6 & 3.6 & 4.2 & 4.9 & 5.3 & 4.5 \\
\hline Net Foreign Direct Investment (\% of GDP) & 1.1 & 2.3 & 3.6 & 3.6 & 3.6 & 2.5 \\
\hline Fiscal Balance (\% of GDP) & -7 & -5 & -4 & -3 & -2 & -1 \\
\hline Debt to GDP Ratio (\% of GDP) & 155 & 145 & 140 & 130 & 125 & 120 \\
\hline
\end{tabular}

Source: Authors Calculation

\subsection{Beirut Port Explosion and Its Consequences}

Lebanon is no victim of destruction and chaos. The tiny nation straddles the Middle East's strategic political divisions and experienced a long civil war that lasted in 1990. It is also criticized for grafting and financial and public mismanagement. Authorities considered this would be caused by the explosion of a warehouse of 2,750 tons of ammonium nitrate placed there, equivalent to 1,800 tons of TNT. In the latest hit, a major huge explosion smashed through the port of Beirut, its capital, on 4 August, killing more than 191 citizens, wounding thousands more and destroying buildings (Haghdoost, 2020). The damage was severe and unbelievable. Within a radius of six miles, households were destroyed and early figures indicate that 300,000 people lost their houses. Hospitals that had already struggled to manage with the first round of COVID-19 patients were already exhausted beyond ability. The wheat storage buildings were totally destroyed which raised concerns over food supplies and the inability of the Lebanese government to import food. This human disaster may also affect the Syrian and Palestine refugees which are approximately 1,800,000. The near future seems grim and definitely, a high number of citizens will be willing to immigrate. The explosion undermined the trust that people may still have had in their political leaders and immediate solutions require at least a comprehensive political change (Hamza, 2020). The estimated physical damage of the explosion ranges between 3.8 and 4.6 billion dollars in addition to the economic damage which is estimated to be between 2.9 and 3.5 billion dollars. The transportation sector, infrastructure, national monuments, theatres, commerce industry, the housing sector, and healthcare assets are all affected by this immense disaster (Byblos Bank, 2020). In addition, the evaluation stated that rehabilitation strategies entail a convergence of approaches that address citizen's needs, specifically the most fragile segments, with systematic reforms tied to macroeconomic stability, governance, operating environment of the private sector, and maintaining human security. More than that, considering Lebanon's current economic condition, foreign assistance and private investments are critical to achieving a sustainable recovery. It stressed that the adoption of a realistic 
reform agenda by the government is a prerequisite to receive international economic aid and to receive support from the foreign and private sectors. On August 18, 2020, the government resigned due to the protestor's pressures and the prime minister blamed the political parties for the explosion announcing that corruption was rooted in every part of the state. The challenge that Lebanon is facing now is to form a new government different from the traditional ones that excluded the ruling class. The new government should include decent members who can help to restore the local and the international community's trust and confidence (Specia \& Chehayeb, 2020). We experienced centuries with almost the same privileged political elite in influence, the useless past of the same ruling establishment, the same institutions, getting control of Lebanon over and corrupting Lebanon over and over (Cooper \& Abadi, 2020).

What Lebanon urgently requires is a new start, a new socio-political contract that gets rid of religious extremism and ensures transparency through constitutional reform. A new election law should be adopted to entail the right representation and the end of the existing corrupted political system. A new government could implement sound reforms that emphasize transparency, accountability, effective management and strategical plans to raise the country from its miserable economic, political and social status (Ghaddar, 2020).

\section{CONCLUSION}

The port of Beirut's explosion and its consequences along with the severe economic crisis, the huge political conflict, the absence of accountability, transparency, and integrity throughout Lebanese public service organizations, the lack of financial commitment toward the international community, the huge public debt, the legislation of bribery and corruption throughout public administration, the reliance on nepotism and confessionalism in public administration represent a poor record for Lebanese government to adopt and execute any strategic plan. The visit of the French President Mr. Emmanuel Macron on September 1, 2020 was a slap in the face of Lebanese politicians to make them wake up and look at the horror of the bad situation the country has reached, and ring the bell, warning that from now on there is no blank check to help Lebanon without strategic reforms, without fighting corruption, and without adopting corporate and new public governance on all state levels. Corporate governance and new public governance present themselves as the ideal approach for adopting the pledge improvements required to optimize outcomes and build on the conditioned and controlled financial resources of CEDRE project. The present research shed the light on the needed reforms in order to develop a new Lebanese public and corporate governance through which CEDRE or Capital Investment Plan could be transformed into a gold revolution that shine throughout the economic, political, and social life. Actually, the shift in the structure of Lebanese governance will be no more avoided, because several organizational inconsistencies triggered mostly by external complexities and expanded the loss of Paris I, II, and III conventions must never be reached. Consequently, Lebanese 
El Ammar, C., El Hajj, W., Kataya, A.

BEIRUT EXPLOSION AND CEDRE IMPLEMENTATION: THE LAST OPPORTUNITY FOR EFFECTIVE CORPORATE

AND PUBLIC GOVERNANCE

government must react to CEDRE rules and regulations from the participants parties by following the strategic reform required which is presented as follows: first of all, Lebanese governments must strictly follow and implement the International Community's guidelines and contribute to the reforms that have been agreed on in order to receive CEDRE funding, achieve credibility and maintain performance and sustainability. Second, the Lebanese government must formulate a strategic reform plan for the Lebanese economy with a vision to reduce the risk of instability, decreases the expense of seeking a feasible solution, fight corruption and bribery, emphasizes the priority of public interest over the private one and, mostly, acquires credibility and legitimacy, thereby improving Lebanese government accessibility to more capital and financial opportunities. The Lebanese government should modify its members (executives, administrative staff, elected officials ...) by implementing the New Lebanese Public Governance, turning their position into a regulator to effectively execute a sustainable strategic reform agenda that supersedes and relies on the CEDRE project conditioned financial resources.

\section{REFERENCES}

Aoki, M. (2001). Towards a Comparative Institutional Analysis. Cambridge, UK: MIT Press.

Barret, P. (1997). Corporate Governance: P-S Style. Australian Accountant.

Barret, P. (1998). Corporate Governance. Canberra: The Defence Audit and Program Evaluation Committee (DAPEC).

Byblos Bank. (2020). Lebanon This Week 646. Retrieved September 6, 2020, from https://www.byblosbank.com/common/economic-research-new/lebanon-this-week/lebanon-thisweek-646/damages-from-beirut-port-explosion-estimated-at-up-to-46bn-economic-losses-at-upto-35bn

Cadbury Committee. (1992). Report of the Committee on the Financial Aspects of Corporate Governance. London: Gee and Co Ltd.

Cadbury, S. (2000). The Corporate Governance Agenda. Corporate Governance: An International Review, 8(1): 7-15.

CIPFA. (1995). Corporate Governance: A Framework for Public Service Bodies. London: Chartered Institute of Public Finance and Accountancy.

Cooper, H., \& Abadi, M. (2020). Lebanon was already in financial crisis before the explosion in Beirut and now experts are predicting devastating consequences. New York: Business Insider. Retrieved September 5, 2020, from https://www.businessinsider.com/beirut-lebanon-explosionfinancial-crisis-economy-2020-8

Council, A. (2007). Corporate governance principles and recommendations. Retrieved September 6 , 2020, from http://www.blackrockmining.com.au/wpcontent/uploads/ASX_Corp_Governance_Principles_Recommendations_2nd_Edition.pdf

Dixit, A. (2009). Governance Institutions and Economic Activity. The American Economic Review, 99(1): $5-24$. 
Ghaddar, H. (2020). Lebanon Needs Transformation, Not Another Corrupt Unity Government. Washington: The Washington Institute. Retrieved September 6, 2020, from https://www.washingtoninstitute.org/policy-analysis/view/lebanon-needs-transformation-notanother-corrupt-unity-government

Haghdoost, Y. (2020). How the Beirut Explosion Will Worsen Lebanon's Crises. Washington Post. Retrieved August 29, 2020, from https://www.washingtonpost.com/business/how-the-beirutexplosion-will-worsen-lebanons-crises/2020/08/14/67547828-dde3-11ea-b4f125b762cdbbf4_story.html

Hamza, W. (2020). How Beirut's port explosion exacerbates Lebanon's economic crisis. Australia: The Conversation. Retrieved August 29, 2020, from https://theconversation.com/how-beiruts-portexplosion-exacerbates-lebanons-economic-crisis-144040

Hardman, B. (1996). Coporate Governance: A Practical Guide for Directors and Secretaries. Australian Company Secretary, 48: 235-238.

Hepworth, N. (1994). Principles of Corporate Governance and the Public Services. London: CIPFA.

Hontz, E., Shkolnikov, A., \& Abell, O. (2009). Corporate Governance: The Intersection of Public and Private Reform. Washington, DC: United States Agency for International Development (USAID) Economic Growth and Trade.

Horwood, I. (2001). Corporate governance in the Public Sector: The Role of Risk Management. Institute of Chartered Accountants of New Zealand (ICANZ).

ICANZ. (2003). Improving Corporate Reporting : A Shared Responsibility : Report for the Minister of Commerce Improving Corporate Reporting in New Zealand: A Shared Responsibility. Wellington: Institute of Chartered Accountants of New Zealand (ICANZ).

IIA. (2006). The Role of Auditing in Public Sector Governance. Institute of Internal Auditors.

International Federation of Accountants (IFAC). (2001). Governance in the Public Sector: A Governing Body Perspective. New York: International Public Sector Study.

Johnston, M. (2012). Good Governance: Rule of Law, Transparency, and Accountability. The World Wide Web.

Retrieved

from http://unpan1.un.org/intradoc/groups/public/documents/un/unpan010193.pdf

Kersbergen, K., \& Waarden, F. (2004). Governance' as a Bridge Between Disciplines: Cross Disciplinary Inspiration Regarding Shifts in Governance and Problems of Governability, Accountability and Legitimacy. European Journal of Political Research, 43: 143-171.

Lindsay, C., Osborne, S., \& Bond, S. (2014). The 'New Public Governance' and Employability Services in an Era of Crisis: Challenges for Third Sector Organizations in Scotland. Public Administration, 92(1): 192-207.

Maher, M., \& Andersson, T. (1999). Corporate governance: Effects on firm performance and economic growth. The World Wide Web. Retrieved from https://www.oecd.org/sti/ind/2090569.pdf

New South Wales Audit Office. (1997). Performance Audit Report on Corporate Governance. Sydney: NSWAO.

Nohria, N., \& Eccles, R. (1992). Networks and Organizations: Structures, Form and Action. Cambridge, Mass: Harvard Business School Press.

Nolan, L. (1995). First Report of the Committee on Standards of Public Life. London: Her Majesty Stationery Office, HMSO. 
Osborne, S. (2010). The (New) Public Governance: A Suitable Case for Treatment? In S. Osborne, The New Public Governance. Emerging Perspectives on the Theory and Practice of Public Governance. London: Routledge.

Patapas, A. (2014). New Public Governance: The Tracks of Change. International Journal of Business and Social Research, 4(5): 25-32.

Pestoff, V., Brandsen, T., \& Verschuere, B. (2012). New Public Governance, the Third Sector and CoProduction. New York: Routledge.

Plessis, J., Hargovan, A., \& Bagaric, M. (2011). Principles of Contemporary Corporate Governance. New York: Cambridge University Press.

Porta, R., Silanes, F., Shleifer, A., \& Vishny, R. (2000). Investor Protection and Corporate Governance. Journal of Financial Economics, 58: 3-26.

Roundtable, B. (2002). Principles of Corporate Governance. Washington, DC.

Roundtable, B. (2010). Principles of Corporate Governance. Washington, DC: Business Roundtable.

Ryan, C., \& Ng. , C. (2000). Public Sector Corporate Governance Disclosures: An Examination of Annual Reporting Practices in Queensland. Australian Journal of Public Administration, 59(2): 11-23.

Specia, M., \& Chehayeb, K. (2020). After the Beirut Blast, Lebanon's Whole Cabinet Quit. Now What? New York: The New York Times. Retrieved September 3, 2020, from https://www.nytimes.com/2020/08/11/world/middleeast/lebanon-government-resignsexplainer.html

Xu, R., Sun, Q., \& Si, W. (2015). The Third Wave of public administration: The New Public Governance. Canadian Social Science, 11(7): 11-21. 